\title{
Women and Negotiations: An Undergraduate Level Study
}

\author{
Lee A. Macenczak \\ Clinical Assistant Professor of Management \\ Kennesaw State University
}

\begin{abstract}
This essay discusses the impact that a negotiations class had on a group of women at a private, liberal arts college. Perceptions, confidence levels, and negotiations frequency were all examined to determine if a significant change could be seen in the participants. Utilizing an experience-based class structure, students were given the opportunity to learn, practice, share feelings, and critique performance. Results indicate that women may benefit from schools offering more access to negotiation classes at the undergraduate level across all disciplines in order to build this critical skillset.
\end{abstract}

\section{Introduction}

In the current competitive environment, researchers have continued to explore methods to improve the leadership development process for current and future female leaders (Debebe, 2011; Diallo \& Gerhardt, 2017; Ely, Ibarra, \& Kolb, 2011) While the number of women in the workforce increased 11\% from 2000 to 2016, data indicates that women's salaries still represent only $81 \%$ of men's salaries and that women continue to be underrepresented in upper management positions (Hill, 2015; Warner, 2014). While there has been a focus on improving access and leadership training opportunities, there is still work to be done.

On a broad basis, to be an effective leader one must usually have the ability to define visions and strategies, exhibit effective decision making, balance risk, effectively communicate to all stakeholders, motivate and influence employees, lead change, and exhibit negotiations skills to manage conflict and finalize decisions (Diallo \& Gerhardt, 2017). Research indicates that leadership is learned and most learning comes from experience (Arvey, Rotundo, Johnson, Zhang, \& McGue, 2006; Arvey, Zhang, Avolio, \& Krueger, 2007). Experiences that we have on the job or through other learning such as training or school, help shape the development of leaders (Douglas, 2003).

Women can miss out on these experiences either through intentional efforts or due to second-generation forms of gender bias. This bias is related to barriers that arise from cultural beliefs about gender, workplace structures and practices, and interactions that favor men (Calas \& Smircich, 2009; Ely \& Meyerson, 2000; Kolb \& McGinn, 2009; Sturm, 2001). Colleges and Universities are becoming more focused on providing leadership development opportunities for all students with many creating leadership development and leadership studies minors for students, regardless of the major concentration of study (Diallo \& Gerhardt, 2017; Dugan \& Komives, 2007; White, 2006).

These programs can be useful in providing students, especially women and minorities, an opportunity to develop core life skills that will be used with regularity in their careers regardless 
of their field of study. The World Health Organization (1999) defined life skills as abilities for adaptive and positive behavior that enables individuals to deal with the challenges of life. This would include social skills, problem-solving, critical thinking, and interpersonal skills. This paper will focus on one key interpersonal life skill set within the leadership area, negotiations, and why schools should offer development opportunities for students, especially women, earlier in the academic process.

\section{Negotiations}

Prior research has posited that one of the demands of being a leader is to align key constituencies through the use of power, persuasion, or negotiations and ensuring that the people required to achieve the goals are aligned (McCall, 2010). Negotiation is defined as an interpersonal decision-making process in which two or more parties are communicating to influence an other's decision whenever we cannot achieve our objectives single-handedly (Thompson, 2015). Regardless of the industry, individuals in almost all professions negotiate something every day (Fisher \& Ury, 1981). While most people do not always recognize that they are negotiating or what can be negotiated, in either their personal or professional life, making it through the day requires us to use this critical communication and influencing tool (Kolb \& McGinn, 2009; Thompson, 2015).

In our personal life, we negotiate with family and friends on a variety of topics or with others outside of our family and friends about major financial decisions like buying a house or a car. In our professional lives, we negotiate salaries and benefit packages when getting a job, with our bosses for project deadlines and days off, with our employees for almost every issue in the workplace, and with customers and suppliers over business arrangements, transactions, and problems that may arise. The negotiation skill set is seen as being increasingly important for managers and leaders to exhibit in the workplace with managers spending up to $20 \%$ of their time in negotiations (Baron, 1989). As the pace of change in this global economic environment requires managers to bring together diverse groups to jointly address problems and take full advantage of the opportunities in the market, being effective at this skill could influence an organization's success (Thompson, 2015).

While the negotiation skill set has been shown to be important to managers, there is some indication that women are less effective at the negotiating table (Stuhlmacher \& Walters, 1999). They claim less value in dividing the pie, have lower aspirations, ask for less value, have more anxiety about the process, and undervalue themselves (Kray, Thompson, \& Galinsky, 2001). Possibly the biggest issue being that women are much less likely to initiate negotiations than their male counterparts (Small, Gelfand, Babcock, \& Gettman, 2007). Women may negotiate less because they miss contextual cues and do not initiate the negotiation process. The issues related to why women negotiate less may be more rooted in cognitive differences and how they react to differences in how issues and decisions are framed (Small et al., 2007).

Since resources in an organization are limited, power struggles in the allocation and decision making process are common. Managers have been advised to become master politicians using power, negotiation and influencing/persuasion skills to more successfully achieve their agendas (Bolman \& Deal, 2003). Power in organizations is negotiated by individuals as a part of 
organizational life where your level of power or status is negotiated regularly (Hanscome \& Cervero, 2003). So, if a group of people do not have the skills to navigate the changing power dynamics in organizations, they will tend to not be as successful as those that do exercise these skills more effectively.

Since negotiation skills are important to effective leadership behaviors and could improve a woman's ability to gain power in an organization, improve their marketability and chances for promotional opportunities, there should be further examination of what colleges and universities can do to more effectively prepare women to enter the workplace. As Ely, Ibarra, and Kolb (2011) said, "Women have not been socialized to compete successfully in the world of men, and so they must be taught the skills their male counterparts have acquired as a matter of course" ( $p$. 475). If schools can give women exposure and experience to negotiating situations where they can learn to better interpret contextual cues, generate options, create negotiating plans, and capture value, they can enter the workplace feeling more empowered which should improve their negotiating position (Hong \& Wijst, 2013).

\section{Study}

A class devoted to negotiations was developed to introduce some diversity in the curriculum at a private, liberal arts women's college. The students were either economics or management majors in their junior or senior year. One of the main priorities of the college is to empower women and it was felt that offering a class on this topic would support that goal. Since this was the first time the class had been offered, data was collected on how the class impacted the students, their views on the topic, and how they would apply the material going forward.

Participants. The class was comprised of 32 students with $41 \%$ being Caucasian, $41 \%$ African American, 9\% Asian, and 9\% Latino. Student ages were primarily between 19 and 22 with one student being in her forties.

Class Design. The class was designed to provide the students with a foundation in negotiation theory and experiences in how to prepare for and participate in an actual negotiation. The students all had little to no experience in actual negotiations. The institution has a majority of traditional students that attend class full-time and do not usually work except on a part-time basis. Because the students had little negotiating experience, the material was structured so that the basics were covered first and then built on gradually through the class. As mentioned earlier, since individuals learn more leadership skills through experience, each section of the material was reinforced by an actual negotiating session that became more difficult as the semester progressed. One of the main goals of the class was to give the students as many negotiating experiences as possible.

There was a total of 12 negotiating sessions throughout the semester ( 8 individual $/ 3$ team/1 overall class). A majority of the cases utilized were purchased from the Dispute Resolution Research Center at the Kellogg School of Management at Northwestern University. The situations in the cases ranged from personal situations like buying a car or home to business transactions to a persuasion session that focused on what patient should receive an organ transplant. For the individual negotiating sessions, students were assigned negotiating partners 
by the professor. This ensured that the students would experience a variety of skills and negotiating styles. All negotiating sessions were timed and performed in class. For more complex cases, information was distributed in prior classes and students were allowed to prepare ahead of time. After the basic skills were discussed in class, students were required to follow a structured process in developing a negotiating plan, so they could successfully conduct the session. The process consisted of a case review, outlining key points, and preparing a detailed negotiating strategy. Following the negotiation, students were required to assess their performance and the performance of the other party.

The team sessions required the students to negotiate first as team to determine their strategy and positions, then complete the session with the other team. These cases were more complicated and required more skills for them to complete. One team session was focused on the skill of persuasion and required each team to present their case on why their patient should receive an organ transplant. It was stressed that this was an exercise that focused on using strong persuasion skills as the class would be deciding who received the organ. During another team negotiating session, all teams on one side the negotiation case were instructed to behave in an aggressive, angry manner during the process for the other group to experience a hostile negotiation. Finally, for them to experience a large negotiating session, the class was offered the opportunity to negotiate whether there would be a final exam. They first had to negotiate internally among the class to determine their position, elect a negotiating committee, and then negotiate a final agreement with the professor.

A critical part of the experience was a detailed de-briefing of each case. Following the completion of the case, results would be summarized and students could see how their results compared against other sessions. The de-briefing time was used to reinforce the skills that were needed in each of the exercises which was critical as each session continued to build on the same set of skills. They were asked the comment on the following questions:

What were the key points in the negotiation?

Did you feel like you claimed or created value?

Were you surprised by the other parties' positions?

What areas could you have improved on?

Will you do anything differently in the next session?

During the de-briefings, students were open and talked freely about their shortcomings, anxieties, and how they prepared for each session. By the end of the semester, the discussions seemed to be a welcomed part of the process. The students were eager to talk about their experiences and what they could do better to claim and create value.

Data Collection. On the first day of class, a survey was distributed to the class in order to capture a base line regarding the students' familiarity with the topic, negotiating experience, and their feelings on the skill set. Questions covered demographics, topics regarding frequency 
of negotiation, their confidence in their negotiation's ability, and how they embrace a situation that requires negotiating. They were also asked to list the top three issues that they felt prevented them from being an effective negotiator.

At the end of the semester, a similar survey was distributed to measure how the class had influenced the students' feelings regarding the topics. Following the completion of the semester, a small group of students were then asked a series of open-ended questions regarding their experiences from the class and the impact, if any, to their future plans.

Results. To compare the results of the data from Time 1 and Time 2, a paired-samples ttest was utilized. The results indicate that after the completion of the class students were more confident in their ability to negotiate, felt more like they could embrace a negotiating situation, and were now more likely to enter into a negotiations process (see Table 1). There was a statistically significant mean increase in expected frequency, $t(31)=3.044, p<.001, d=.5381$, confidence, $t(31)=5.00, p<.001, d=.884$, and the embracing of the situation, $t(31)=5.685, p$ $<.001, d=1.005$.

Table 1. Summary of Surveys

\begin{tabular}{lcccc}
\hline & \multicolumn{2}{c}{ Time 1 } & \multicolumn{2}{c}{ Time 2 } \\
\cline { 2 - 5 } Frequency & $\mathrm{M}$ & $\mathrm{SD}$ & $\mathrm{M}$ & $\mathrm{SD}$ \\
\hline Confidence & 4.00 & 0.950 & 4.28 & 0.581 \\
\hline Embracing the situation & 3.09 & 0.734 & 3.72 & 0.683 \\
\hline
\end{tabular}

The next step was to classify the free form comments made by students at the start of the class regarding the top 3 issues that prevented them from being an effective negotiator. Two colleagues were asked to sort the individual comments into groups with common themes. The process resulted in 4 distinct categories being established: personality, conflict avoidance, lack of experience/skills, and confidence. While a lack of experience/skills could be considered a byproduct of the young age of the students, the other groupings provide an insight into why young women shy away from negotiating. Many comments were made that their personality was not suited to participate in a negotiation session or that they didn't think they could be forceful enough during the process due to their personality. There was also a very clear sense that they had little confidence in their own abilities and did not like the thought of possibly having a negotiation turn into a conflict situation. They also expressed concern that they didn't have the right skills to conduct a negotiation and felt that others had always taken care of them in these situations. Examples of the statements are listed in Table 2. 
Table 2. Sample Comments - Barriers to being an effective negotiator

\begin{tabular}{ll}
\hline Lack of confidence & Unsure of what to say or do \\
\hline Inability to make decisions & No knowing something is negotiable \\
\hline Fear of ending up worse than before & Assertiveness \\
\hline Not knowing when to negotiate & I'm introverted \\
\hline No wanting to cause conflict & I don't like to debate \\
\hline Not having an outing personality & I am too nice \\
\hline Lack of confidence & I don't want to offend someone \\
\hline Not sure how to prepare & I usually like to please others \\
\hline Lack of experience & I would usually just remain quiet \\
\hline I undervalue myself & I don't want to lose \\
\hline What if they say no & Not sure where I begin \\
\hline I sell myself short & I don't like conflict \\
\hline Too emotional & Financial discussions make me anxious \\
\hline I don't like causing issues, so I'm a pushover & Being a minority female \\
\hline
\end{tabular}

Following the completion of the class, 6 students were interviewed about their experience in the class, its benefits, and their impression of how the course had impacted them. Each was interviewed and asked the same set of questions. The questions centered on how the class had changed their view of their careers, their confidence levels, how they would approach a negotiating situation, and whether they thought the material was appropriate for an undergraduate level class.

Being able to practice in a safe environment turned out to be an important point. These students were afraid of failing in public and having the ability to practice a skill they had little exposure to improved their confidence. They expressed that having a process to utilized when presented with a negotiating situation is invaluable to them. Since most had always had others do their negotiating for them, they felt a sense of empowerment that they could do it themselves. They also liked hearing about my failures as a negotiator. Many commented is was good to hear that things don't always go your way and that you can learn from the failures. Lastly, most believed that the class should be required for female undergraduate students and that the material was appropriate for this level. The questions and the student's responses have been summarized in Table 3.

Table 3. Summary of Responses

Questions Sample Comments

How did the class improve your confidence level when thinking about negotiation sessions that you may encounter?
Sample Comments

I have new skills and am now aware of the process and situations that can be negotiated.

Being able to practice in a controlled environment was invaluable.

The class exposed a gap of self-esteem that I was unaware of. I feel more empowered to represent myself and take more control of my life. 
I go on the job market soon and now feel I can effectively negotiate my package without looking like an amateur.

Now I know how to prepare. I feel like I can handle any situation that comes to me.

Nice to hear from an instructor about how they had failed negotiating things in their career.

Did the class change how you view your career?

Has it changed your confidence level about being successful in your chosen career field?

Do you feel that the knowledge from the class will improve your chances of success?

Are you more likely to approach conflict situations differently now?
Yes, I now want to be a negotiator. I want to attend law school and then enter the conflict resolution field.

I will stay on same career path but feel the skills will benefit me in professional and personal life.

I have a financial analysis internship this summer and feel more confident in my ability to assert myself.

I have a great deal more confidence about my chances at being successful even with the deck stacked against me.

Yes, I now have a process to follow to be prepared and am knowledgeable about the different ways to achieve an outcome.

I will always have a well thought out BATNA.

I feel more confident in dealing with situations on a daily basis. I tend to view the differently knowing how to frame my options.

My parents and other teachers already hate my new skills. My ability to standup for what I want is now stronger than before. It has also helped me deal more effectively with other students.

It has greatly improved my decision making. I think more about how to frame situations.

\section{Was the material appropriate} for undergraduate level students?
Yes, it should be a required course, especially for women.

I think all students should take this along with public speaking and personal branding, very empowering.

Most undergrads lack confidence in themselves and their direction. This class was very useful in creating confidence for both of those areas.

Very useful both professional and personally. 


\section{Conclusion}

While the sample size for this study is small and represents the results from only one class, the results speak clearly as to the possibilities if there is a focus on improving core, lifebased skills for future female leaders. Some believe that by failing to negotiate women look weak, ignorant, and clueless in the workplace (Tack \& McNutt, 2004). The results of the class show that women participating in this class had a significant positive change in their thoughts and behaviors. It is uncertain as to whether these feelings will continue in the future, but they now have an experience to fall back on when presented with a negotiating opportunity.

As managers across all industries are required to negotiate, colleges and universities should do a better job of preparing all women, not just those in the business and legal community, to utilize this key skill. While most large schools offer courses on negotiations at the undergraduate and graduate level, it is usually offered as an elective. While it may not deserve to be a required course, it does need to be marketed in a new, creative way. Women need to understand the difficulties and barriers they will face in their careers. Many of the challenges can be addressed by becoming an effective negotiator. While this specific class experience was at a women's college, consideration should be given to the possibility of offering negotiation courses targeting women at co-ed institutions.

As stated, in the beginning of the article, we negotiate in almost every phase of our life, both personally and professionally. Most everyone will make a major purchase or be offered a new position. Having this skill can improve your chances of success and give you more control over major aspects of your life. As with most life-based skills, the more you do it, the better you get. This study showed that confidence, frequency, and how they would approach negotiation situation all significantly changed in a positive manner following the completion of the class. If these results can be repeated, sustained, and reinforced over time, the educational process has the opportunity to positively impact the skillsets of our future women leaders. As the treatment of women in the workplace continues to fall short, there may not be a better time to make the investments in skills that improve their chances of success at every level of the organization.

\section{References}

Arvey, R. D., Rotundo, M., Johnson, W., Zhang, Z., \& McGue, M. (2006). The determinants of leadership role occupancy: Genetic and personality factors. The Leadership Quarterly, 17(1), $1-20$.

Arvey, R. D., Zhang, Z., Avolio, B. J., \& Krueger, R. F. (2007). Developmental and genetic determinants of leadership role occupancy among women. Journal of Applied Psychology, 92(3), 693-706.

Babcock, L., Gelfand, M., Small, D., \& Stayn, H. (2006). Gender differences in the propensity to initiate negotiations. In D. De Cremer, M. Zeelenberg, \& J. K. Murnighan (Eds.), Social psychology and economics (pp. 239-262). Mahwah, NJ: Erlbaum. 
Baron, R. A. (1989). Personality and organizational conflict: Effects of the type A behavior pattern and self-monitoring. Organizational Behavior and Human Decision Processes, 44(2), 281296.

Bolman, L. G., \& Deal, T. E. (2003). The political frame. Reframing organizations: Artistry, choice, and leadership (6th ed.). San Francisco, CA: Jossey-Bass.

Calas, M. B., \& Smircich, L. (2009). Feminist perspectives on gender in organizational research: What is and is yet to be. In D. Buchanan \& A. Bryman (Ed.), The sage handbook of organizational research methods (pp. 246-269). Thousand Oaks, CA: Sage Publications.

Debebe, G. (2011). Creating a safe environment for women's leadership transformation. Journal of Management Education, 35(5), 679-712.

Diallo, L., \& Gerhardt, K. (2017). Designing academic leadership minor programs: Emerging models. Journal of Leadership Education, 16(2), 92-108.

Douglas, C. A. (2003). Key events and lessons for managers in a diverse workforce: A report on research and findings. Greensboro, NC: Center for Creative Leadership.

Dugan, J. P., \& Komives, S. R. (2007). Developing leadership capacity in college students: Findings from a national study. College Park, MD: National Clearinghouse for Leadership Programs.

Ely, R. J., Ibarra, H., \& Kolb, D. M. (2011). Taking gender into account: Theory and design for women's leadership development programs. Academy of Management Learning \& Education, 10(3), 474-493.

Ely, R. J., \& Meyerson, D. E. (2000). Theories of gender in organizations: A new approach to organizational analysis and change. Research in Organizational Behavior, 22, 103-151.

Fisher, R., \& Ury, W. L. (1981). Getting to yes: Negotiating agreement without giving in. Boston, MA: Houghton Mifflin.

Hanscome, L., \& Cervero, R. (2003). The impact of gendered power relations in HRD. Human Resource Development International, 6(4), 509-525.

Hill, C. (2015). The simple truth about the gender pay gap. American Association of University Women. Washington D.C.

Hong, A. P., \& Wijst, P. J. (2013). Women in negotiation: Effects of gender and power on negotiation behavior. Negotiation and Conflict Management Research, 6(4), 273-284.

Kolb, D., \& McGinn, K. (2009). Beyond gender and negotiation to gendered negotiations. Negotiation and Conflict Management Research, 2(1), 1-16. 
Kray, L. J., Thompson, L., \& Galinsky, A. (2001). Battle of the sexes: Gender stereotype confirmation and reactance in negotiations. Journal of Personality and Social Psychology, 80(6), 942-958.

McCall, M. W. (2010). Recasting leadership development. Industrial and Organizational Psychology, 3(1), 3-19.

Small, D. A., Gelfand, M., Babcock, L., \& Gettman, H. (2007). Who goes to the bargaining table? the influence of gender and framing on the initiation of negotiation. Journal of Personality and Social Psychology, 93(4), 600-613.

Stuhlmacher, A. F., \& Walters, A. E. (1999). Gender differences in negotiation outcome: A metaanalysis. Personnel Psychology, 52(3), 653-677.

Sturm, S. (2001). Second generation employment discrimination: A structural approach. Columbia Law Review, 101, 458-568.

Tack, M. W., \& McNutt, M. S. (2004). Women and negotiations: Unveiling some secrets to success. The Journal of Leadership Education, 3(3), 63-71.

Thompson, L. (2015). The mind and heart of the negotiator (6th ed.). Upper Saddle River, NJ: Prentice Hall Press.

Warner, J. (2014). The women's leadership gap: Women's leadership by the numbers. Center for American Progress,

White, B. J. (2006). Design and implementation of an interdisciplinary leadership studies minor at an historically black, liberal arts college. Journal of Leadership Education, 5(2), 50-59.

World Health Organization. (1999). Partners in life skills training: Conclusions from a united national inter-agency meeting. Geneva, Switzerland: World Health Organization.

\section{Author Biography}

Lee Macenczak is a Clinical Assistant Professor of Management at Kennesaw State University. He received his DBA in management from Kennesaw State University and a masters in management from Georgia State University. Before earning his doctoral degree, Dr. Macenczak spent 23 years as an executive in the airline industry. His research has focused on leadership, justice perceptions, power, narcissism, and decision making. lmacencz@kennesaw.edu. 